\title{
NBSIR $73-412$
}

\section{The Incidence of Hazardous Material Accidents During Transportation and Storage}

W. A. Steele

D. Bowser

R. E. Chapman

Technical Analysis Division National Bureau of Standards Washington, D. C. 20234

November 1973

Final Report

\section{Prepared for}

Center for Building Technology National Bureau of Standards

Washington, D. C. 20234 

NBSIR 73-412

THE INCIDENCE OF HAZARDOUS MATERIAL ACCIDENTS DURING TRANSPORTATION AND STORAGE
W. A. Steele
D. Bowser
R. E. Chapman

Technical Analysis Division National Bureau of Standards

Washington, D. C. 20234

November 1973

Final Report

Prepared for

Center for Building Technology

National Bureau of Standards

Washington, D. C. 20234

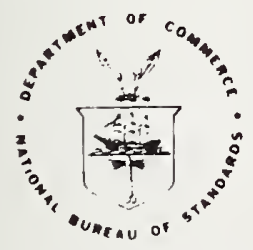

U. S. DEPARTMENT OF COMMERCE, Froderick B. Dent, Secretary 



\section{CONTENTS}

1. INTRODUCTION $\ldots \ldots \ldots \ldots \ldots \ldots \ldots \ldots \ldots \ldots \ldots \ldots \ldots \ldots$

2. SCOPE OF PROJECT $\ldots \ldots \ldots \ldots \ldots \ldots \ldots \ldots \ldots \ldots \ldots \ldots \ldots \ldots \ldots$

3. PIPELINE tRANSPORTAtion OF HAZARdoUs MAtERIALS ..... 10

4. WATER tRANSPORTAtion OF HAZARDOUS MATERIALS ...... 13

5. MOTOR VEHICLE TRANSPORTATION OF HAZARDOUS

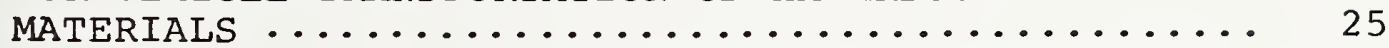

6. RAILROAD TRANSPORTATION OF HAZARDOUS MATERIALS .... 29

7. STORAGE OF HAZARDOUS MATERIALS ............. 32

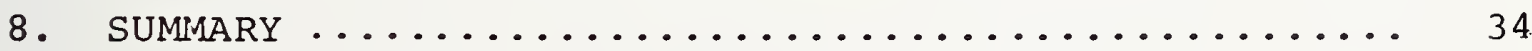

9. LIST OF REFERENCES ...................... 36 



\section{INTRODUCTION}

There has been growing international concern that buildings, particularly multistory residential buildings, may be subjected to loading conditions not normally considered in design -- abnormal loadings. The concern was initiated in 1968 with the much-publicized collapse of the Ronan Point apartments in London. In this 22-story building of precast concrete panel construction, collapse was triggered by an accidental explosion of gas (an abnormal loading) that leaked from the 18th floor. As a result of the explosion, one corner of the building collapsed.

In November 1971, the Department of Housing and Urban Development requested the National Bureau of Standards to make a study of all aspects of abnormal loading and the problem of progressive collapse. A discussion of several sources of abnormal loading is reported elsewhere [1]. ${ }^{1}$ Several of these types of loading are considered to have a frequency of occurrence large enough to warrant particular attention.

This report is one of a series describing background research concerning the incidence of abnormal loading; in this case accidents resulting from the transport and storage of of hazardous materials, including qualitative judgments regarding prespective risks. The effect on building of the

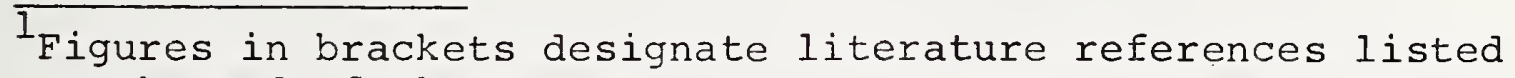
at the end of the report. 
abnormal loading discussed herein, as well as others reported in the series, will be contained in a future report on abnormal loading and building safety. 


\section{SCOPE OF PROJECT}

Although there have been few cases of collapse of buildings due to accidents with hazardous materials, there is a basis for increasing concern since: (a) multistory construction using new technology has grown over the past decade, meaning more buildings may be susceptible to collapses each year; (b) the quantities of hazardous material (particularly petroleum products and other chemicals) being produced and transported have grown to keep pace with the expanding U.S. economy; and (c) many types of chemicals now being transported are of a more volatile nature and their behavior is often not well understood.

One would like to examine these three trends to determine the magnitude of each in creating potential progressive collapse related explosions. Unfortunately, it has not been possible to develop analytical predictions of these occurrences, largely due to the scarcity of data and the diversity of collection procedures.

This report outlines the major trends in hazardous material transport and storage. Where possible, bounds are placed on the probabilities of accidents involving these materials.

The report is organized in terms of methods of házardous material transportation and storage. These methods-Pipeline, Water, Motor Vehicle, and Railroad Transportation Systems are addressed in the next four sections, respectively, with Storage systems discussed in a fifth. The length of each 
section is based on the amount of available data and not necessarily on the risk involved in an accident. Section 8. contains a summary of the results from these five sections. A list of references compiled during the study is provided in Section 9 .

Before describing the effects of changes in the operations of each mode, consider the changes in the magnitude of the problem at hand. Table 1 shows the increase since 1938 in transportation of crude petroleum and its products [2]. The table shows that the total goods transported has grown at an annual rate of 5 percent since 1938. Of the 1970 total of 1.69 billion tons per annum, about 47 percent is carried through pipelines, 24 percent by water carriers, 28 percent by motor carriers, and 1 percent by railroads.

These products-crude oil, gasoline, liquid petroleum gas (LPG), kerosene, jet fuel, etc. - are volatile liquids which have been transported on a mass scale for many years, but they are not the only ones of interest. Hydrogen, liquid natural gas (LNG), ammonia, vinyl chloride, and cyclohexane are a few others which are now being used on significantly larger scales than ever before. Furthermore, according to Strehlow [3], much less is known of the properties of these substances when released into the atmosphere. 
TABLE I

Total Crude Petroleum and Products in Domestic Transportation in $10^{6}$ tons of 2,000 pounds per ton

\begin{tabular}{cccccc} 
Total & Pipeline & $\begin{array}{c}\text { Water } \\
\text { Carriers }\end{array}$ & $\begin{array}{c}\text { Motor } \\
\text { Vehicles }\end{array}$ & Railroads \\
\cline { 5 - 6 } 360 & 140 & & 140 & 20 & 60 \\
480 & 200 & 120 & 80 & 80 \\
690 & 260 & 240 & 120 & 70 \\
860 & 360 & 270 & 180 & 50 \\
1010 & 430 & 300 & 250 & 30 \\
1200 & 520 & 340 & 310 & 30 \\
1570 & 730 & 360 & 450 & 30 \\
1690 & 790 & 400 & 470 & 30
\end{tabular}

Source: [2] 
The number of explosions caused by ignition of unconfined vapor clouds (the admixture with air of volatile solvents and combustible gases in the open air) over the last forty years is shown in table 2. These figures are approximate because reporting procedures were not well defined in earlier years and some sample data seemed to include only the most spectacular explosions. However, several trends do appear to exist. Unconfined vapor cloud explosions (which are only one component of all accidents) have dramatically increased from 0.4 accidents per year to a current rate of about 7.5 accidents per year. At the same time, the average damage per accident has also increased by an order of magnitude. Extrapolating these trends would imply more accidents in the future, due to unconfined vapor clouds, each of a more costly nature.

Although the two tables do not present a conclusive picture that total hazardous material transportation presents a serious risk to residential multistory dwellings, they do show that: (a) more material is being moved and (b) that accidents which occur today seem to be much more serious than those of a few decades ago.

Ideally, one would like to know (at the very least), the total amounts of each dangerous material transported in the vicinity of "damageable" buildings. Unfortunately, there is a severe paucity of data and deficiencies in the nature in which they are collected. The general difficulty of collecting relevant information, experienced by other researchers in 
Table 2: Unconfined Vapor Clouds (U. S. and Europe)*

\begin{tabular}{|c|c|c|c|c|}
\hline & $\begin{array}{l}\text { Explosions/ } \\
\text { Year }\end{array}$ & $\begin{array}{l}\text { \& involving } \\
\text { IP or Butane }\end{array}$ & $\begin{array}{l}\text { Average Loss/ } \\
\text { Reported Expl. } \\
\quad\left(\$ \times 10^{6}\right) \\
\end{array}$ & $\begin{array}{c}\text { Average Loss/ } \\
\text { Year } \\
\left(\$ \times 10^{6}\right) \\
\end{array}$ \\
\hline $1930-39$ & 0.4 & 100 & 0.25 & .03 \\
\hline $1940-49$ & 1.2 & 50 & $1.50(0.9) * *$ & $.7(.4) * *$ \\
\hline $1950-54$ & 3.4 & 71 & 0.19 & .4 \\
\hline $1955-59$ & 3.4 & 88 & 0.50 & .9 \\
\hline $1960-64$ & 3.6 & 33 & 0.33 & .8 \\
\hline $1965-69$ & 5.0 & 28 & $6.84(2.74) * *$ & $26 \quad(10) * *$ \\
\hline $1970-71$ & 7.5 & 27 & 2.27 & 12.5 \\
\hline
\end{tabular}

*Figures were derived from Table 1 of [3]

**Average when single catastropic explosion of period is removed. 
the field, has (in fact) led the office of the secretary of Transportation, DOT, to initiate research by the Technical Analysis Dividion (TAD) of the National Bureau of Standards in an effort to improve the situation.

As an example of the difficulties present in learning about goods being transported, an excerpt from Motor Vehicle Standards for Hazardous Material Transportation [16] is quoted below.

Other [than DOT] sources of accident data were trucking and safety associations, state agencies and private companies. Different types of organizations collect accident data for different reasons. The result of this, of course, is that they universally collect few facts of any value to the investigation while the bulk of their information is aimed at specialized needs. Some associations use selected segments of Department of Transportation data either as is or in a new format to express information germane to their particular association.

A basic limitation of the available incident/ accident data is that the groups (federal, state, insurance companies, truck owners) requiring the information, have different reasons for collecting the data. As a result, and because of associated costs of collecting and storing data, most of the data is sketchy and lacks uniformity. Although insurance companies and Eleet owners collect large quantities of accident data that could be useful, they are not made available because of litigation problems or unwillingness to divulge private company records.

The National Transportation Safety Board, which is in charge of investigating "serious" accidents and making recommendations for new Federal Standards, summed up its own frustration in the 1971 Annual Report to Congress [5]. 
At this time, neither the modal administrations ${ }^{1}$ nor the National Transportation Safety Board is investigating properly an adequate number of surface transportation accidents for the purpose of preventing their recurrence. The problem, for the most part, rests with insufficient resources. As a result, adequate accident data are not available. Without such data, the effectiveness of the Safety Board's recommendations cannot be assured and agencies responsible for transportation safety do not have access to information needed to make safety program decisions.

"Modal administrations" are DOT units involved in establishing and enforcing rules and regulations regarding the transportation of commodities. These units are the USCG, the FAA, the FRA and the FHA. 


\section{PIPELINE TRANSPORTATION OF HAZARDOUS MATERIALS}

The setting of Federal pipeline standards and investigations of "major" system failures has been the responsibility of the Office of Pipeline Safety (OPS) of the Department of Transportation since late 1968. These investigative and regulatory responsibilities have been separated on the basis of lading, with natural gas pipelines and liquid pipelines being the two categories.

The hazard associated with natural gas pipelines has been analyzed by Burnett, Somes, and Leyendecker [6]. Therefore, the danger posed by natural gas pipelines is excluded here.

The incidence of liquid pipeline accidents is probably somewhat easier to measure. The nature of recorded liquid pipeline incidents is such that accident records, and not the hazard, appear to be the best component for analysis. Table 3 shows accident data collected by the Office of Pipeline Safety and (before OPS's creation) by the Office of Hazardous Materials of the Federal Railroad Administration [7]. As can be seen, the overall trend in accident rates is downward; decreasing by almost 40 percent between 1968 and 1971.

Combined with this marked increase in safety is the nature of these liquid pipelines: for the most part they serve to transport crude materials between natural sources and processing plants. By nature this leads them mainly 
TABLE 3

Liquid Pipeline Accidents During Operations by Commodity Involved

\begin{tabular}{|c|c|c|c|}
\hline 1968 & 1969 & 1970 & 1971 \\
\hline 332 & 246 & 216 & 172 \\
\hline 79 & 62 & 63 & 51 \\
\hline 43 & 48 & 24 & 39 \\
\hline 29 & 23 & 15 & 21 \\
\hline 9 & 6 & 9 & 4 \\
\hline 7 & 2 & - & 5 \\
\hline 6 & 8 & 10 & 5 \\
\hline 3 & 1 & 2 & 2 \\
\hline 1 & - & - & - \\
\hline- & 7 & 8 & 9 \\
\hline
\end{tabular}

Others 
through low density rural areas, particularly in the south central states such as Texas, Oklahoma, Kansas, Louisiana and Missouri. In fact, these five states (10 percent of the union comprising 12 percent of the National Population in 1970) accounted for 56 percent of the liquid pipeline accidents between 1968 and 1971 .

The reported Iiquid pipeline accidents for 1971 [7], included only 8 injuries and one death out of 308 accidents from 19 different causes. It appears, therefore, that although serious accidents caused by liquid pipeline explosions have occurred, they are not likely to become a significant hazard assuming current trends of a decreasing number of accidents continue. 


\section{WATER TRANSPORTATION OF HAZARDOUS MATERIALS}

According to statistics published by the American Waterways Operators, Inc., [8], inland freight traffic for all modes of transportation in the United States in 1970 totaled 3.5 billion tons. The Army Corps of Engineers reports a total of 1.56 billion tons of waterborne commerce for the U.S. in 1970. Of this amount, 710 million tons were transported over inland waterways and the Great Lakes. An additional 238 million tons of cargo were transported by water in coastal and coast-wide traffic. Thus water commerce represents a sizable fraction of the total of U.S. commercial transportation.

In 1967, an estimated 414 million tons of hazardous materials were shipped via water carriers. This constituted approximately 23 percent of the total quantity of hazardous materials shipped in the United States. By 1980, this figure is expected to be approximately 470 million tons, a 13.5 percent increase. Approximately 17 percent of all crude petroleum products is shipped via water carriers. Petroleum and petroleum products constitute approximately 84 percent of all hazardous materials shipped via water carriers. [8] Also see table 4 .

A breakdown of the major petroleum products shipped by water is shown in table 5. Although other waterborne cargoes may present an explosive hazard to buildings, petroleum far outstrips the others as the source of possible damage. The 
potential for a major fire exists whenever combustible liquids or gases (such as petroleum and LNG) are discharged overboard. In addition, marine casualties have occurred where the petroleum cargo contributed to explosions. One example is the collision involving the cargo vessel SS African Star and the $\mathrm{M} / \mathrm{V}$ (motor vesses) Midwest Cities and Tow barge in Mississippi on March 16, 1969 [9]. Seventeen people were killed, four missing and presumed dead and forty injured. Another example is the Meljoy Transport Company tank barge MOS 106 that caught. fire and exploded at the Triangle oil Refining Company loading facility on the upper Mississippi River at La Grange, Missouri, on Nov. 12, 1969 [10]. Tank barge MOS 104 and towboat $M / V$ Martin were also moored at that facility and were involved in the subsequent fire. Six persons were killed and one was injured seriously.

The potential for a major incident arises from the growing level of traffic and volume of commerce on the waterways of the U.S., including greater tonnages of petroleum. Figure 2 shows the growing level of waterborne commerce over the last 23 years. The upward trend is expected to continue. Two other factors may affect the involvement of hazardous materials in castastropic incidents. The National Transportation Safety Board projects that, by 1980, supertankers and LNG tank vessels will transport 50 percent of the oil and natural gas needed in the United States. The largest tanker now in use in the United states has a cargo capacity 
Figure 1: Principal Commodities Carried by Water* Calendar Year 1970, Total Commerce

in the United States

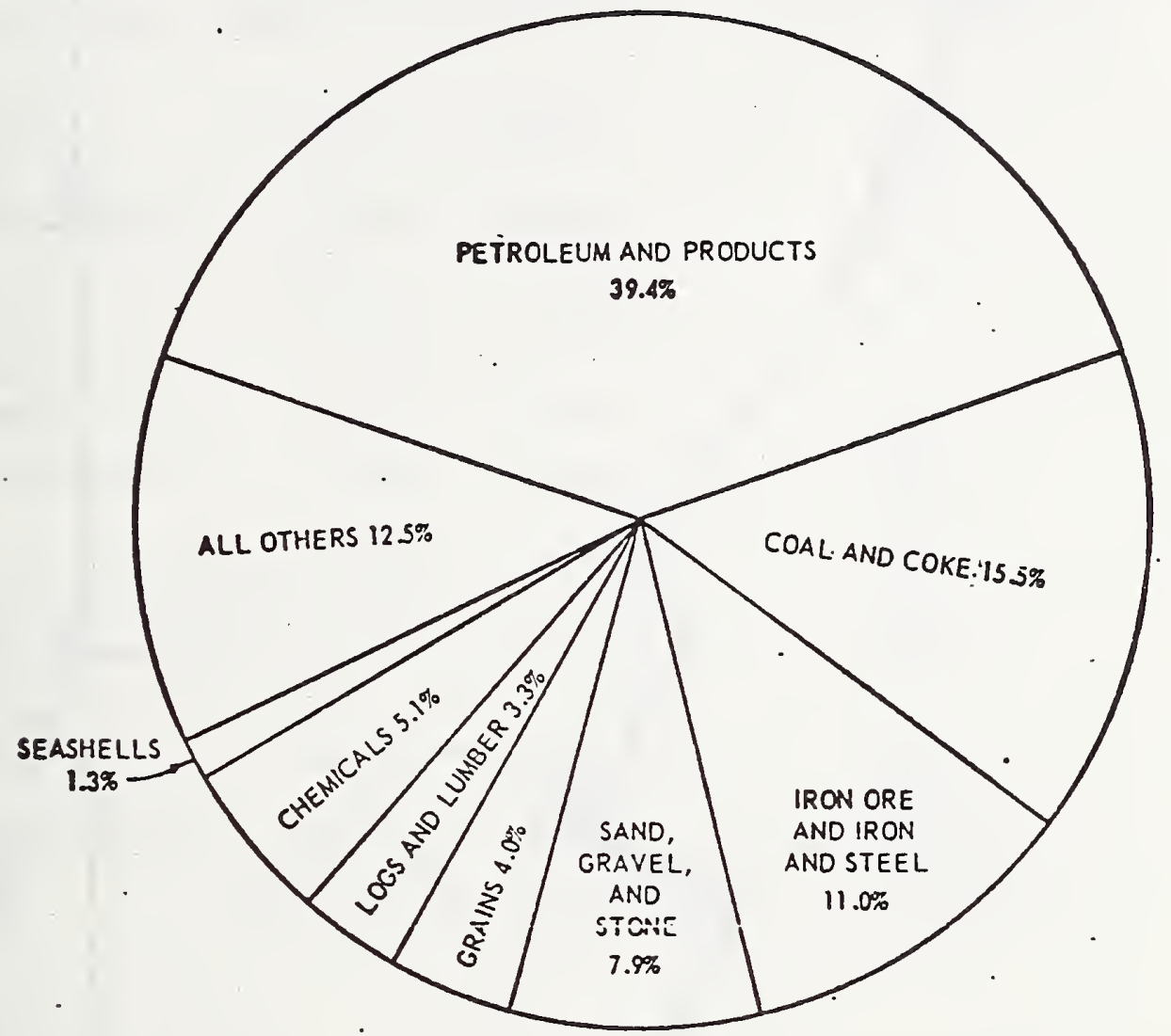

FOREIGN COMMERCE

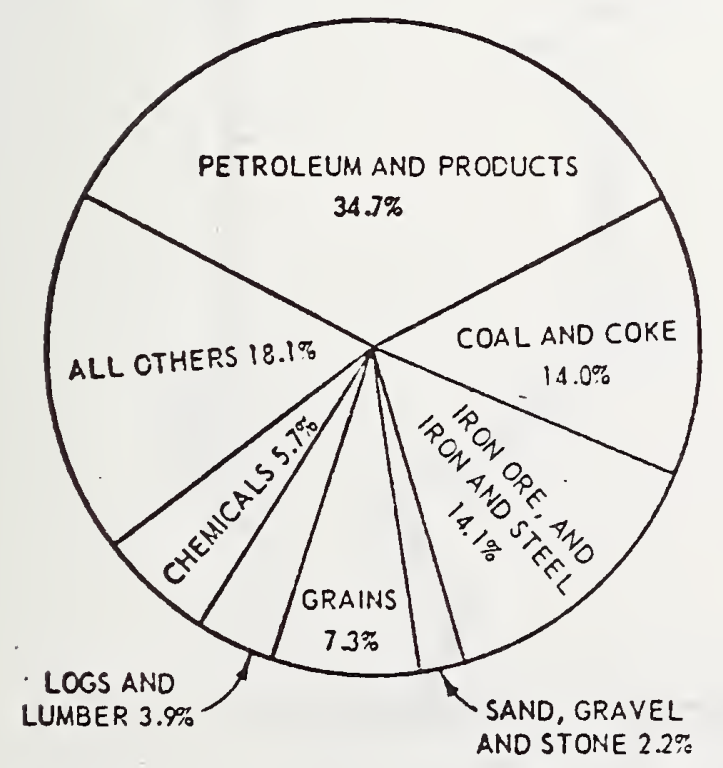

DOMESTIC COMMERCE

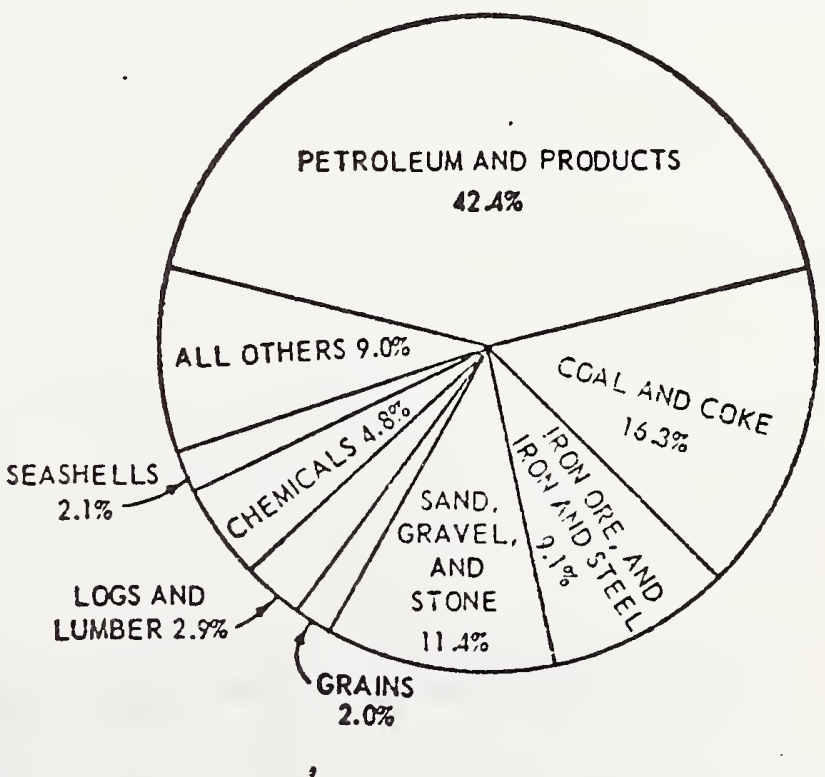

* Taken from [11]. 


\section{TABLE 4}

Hazardous Materials Production

\section{Produced \& Handled* ' * Increase}

\& Increase

Classification 1968-69

1979-80 $1968-69 \quad 1979-80$

Per Year

Flammable materials

$1,620.0 \quad 2,420.0$

50

3.8

Compressed gases

$508.0 \quad 1.067 .0$

110

7.0

Explosives

20.0

40.0

100

6.5

Corrosive

materials

45.1

95.9

112

7.1

Oxidizing agents

7.8

19.4

8.6

Poisons

1.2

2.6

149

7.3

Etiologic materials

7.8

117

- -

Cryogenic materials 36.0

92.0

156

8.9

Radioactive

materials

$17.00 * * 163.0 * *$

860

22.8

Molten materials

$13.0 \quad 41.0$

215

15.0

Total

$2,258.9 * * * 3,778.1 * * *$

$67 * * *$

* Millions of tons

**Thousands of tons

***Computational errors in the oifiginal table have been corrected. 
of 350,000 tons, and the largest tanker under construction (to be completed in the summer of 1973) will have a capacity of 460,000 tons. The technology now exists to construct a tanker with the capacity to carry 1,000,000 tons [12] and such a tanker may be a reality in the future. Should such a vessel be involved in a casualty, its increased volume of cargo could magnify any resulting damage. At the same time its size could prevent it from navigating within a dangerous distance of damageable buildings.

Casualty files for marine accidents are maintained by the Office of Information and Analysis of the U.S. Coast Guard. Casualties involving commercial vessels are required to be reported to the coast Guard whenever the casualty results in the following:

(a) Actual physical damage to property in excess of $\$ 1,500$.

(b) Material damage affecting the seaworthiness of efficiency of a vessel.

(c) Stranding or grounding.

(d) Loss of life.

(e) Injury causing any persons to remain incapacitated for a period in excess of 72 hours; except injury to harbor workers not resulting in death and not resulting from vessel casualty or vessel equipment casualty.

The form used by the Coast Guard for coding reports is shown in Figure 3. Separate categories are coded for damage to the 


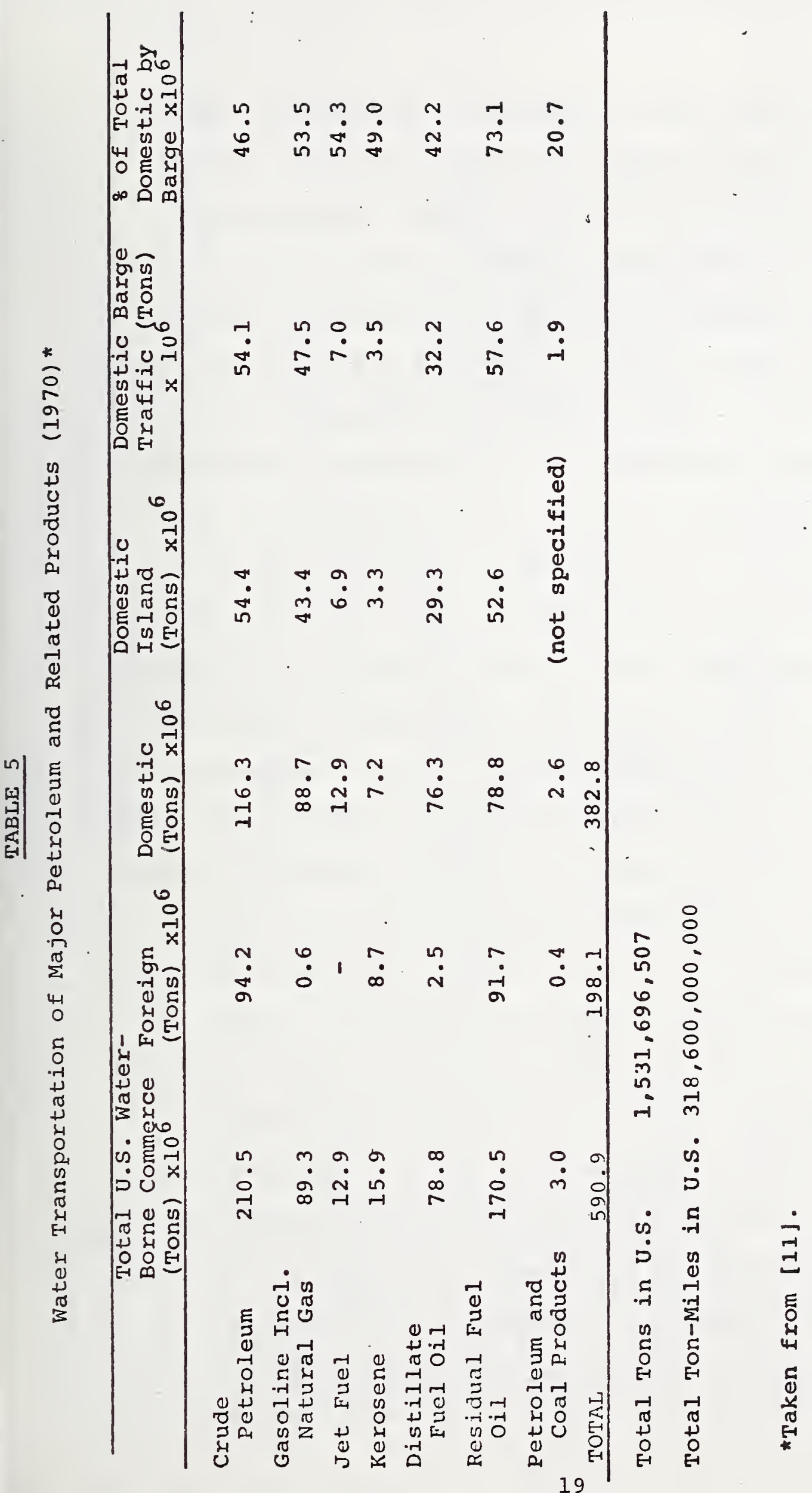


vessel, to the cargo, and to property. A computer listing for the coded accident reports has been searched, and all accidents occurring in 1970 with property damage greater than or equal to $\$ 1,000$ were noted. A total of 207 were found. It was thought that those casualties with property damage greater than or equal to $\$ 100,000$ (13 incidents) would be the most likely to have involved buildings and hence warranted further investigation. The uncoded reports were obtained and examined, but none of them made mention of damage to buildings. Lt. Commander Lauridsen, Head of the Information and Analysis office, does not recall any incidents in past years where extensive damage to a building has occurred. Although building damage may have occurred in some of the 194 unexamined cases, it seems reasonable to assume that any such damage was minor. Despite the probable minor damage, there are reported incidents which could have caused building damage under slightly varied conditions. In addition to, the files just mentioned, the office of Information and Analysis compiles a statistical summary of casualties [13]. For the fiscal year 1971, a total of 2,577 reported casualties involved 4,152 vessels. Of these casualties, 176 (6.83 percent) were due to fire and/or explosion (and many of these could have involved hazardous materials). Another 175 casualties ( 6.80 percent) were due to collisions while anchored, docking, or undocking. Twis latter category includes instances where buildings are most likely to be in 


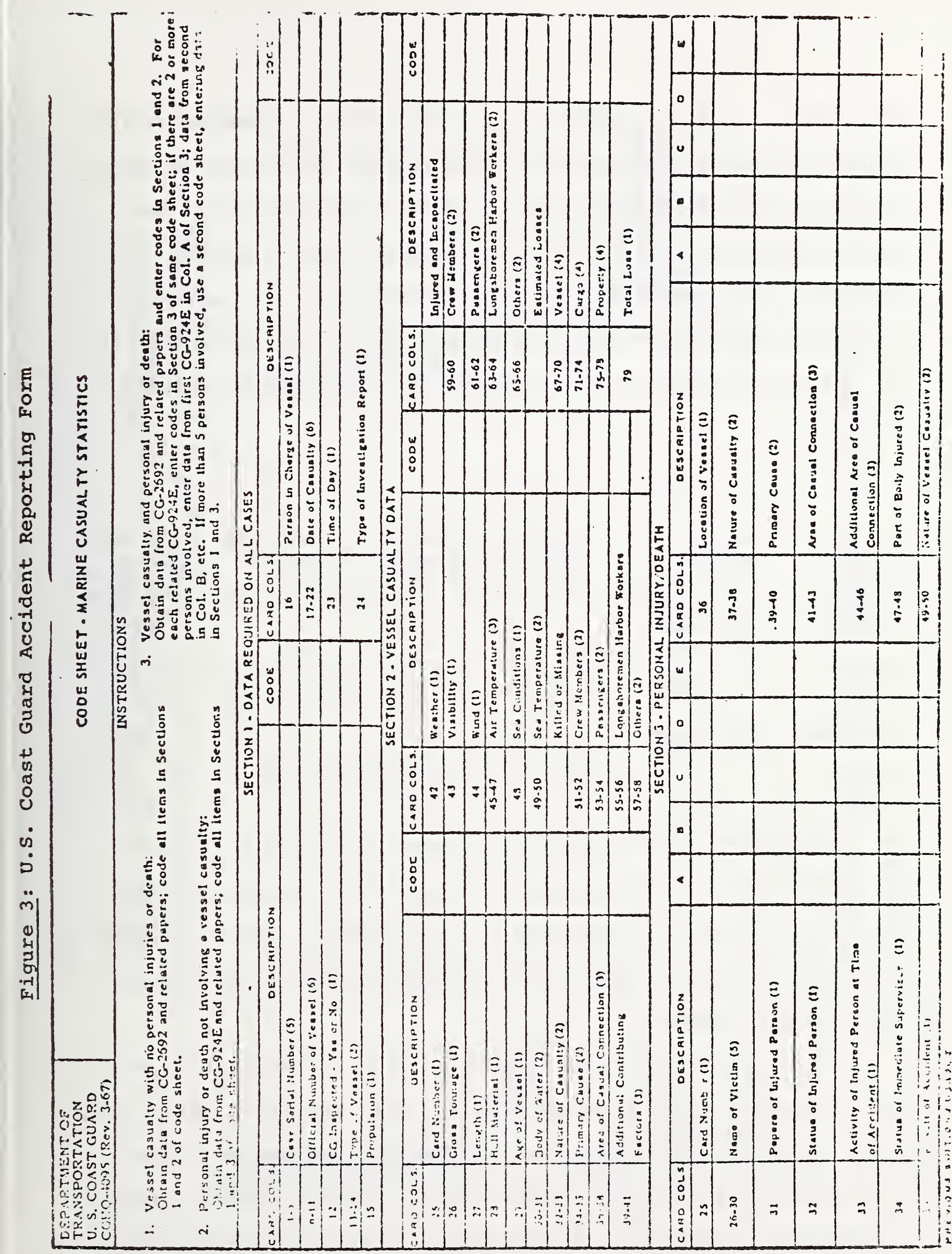


the near vicinity. Should vessels involved in casualties in either of these two categories be carrying hazardous material, extensive building damage might ensue. Unfortunately, the summary does not categorize accidents by type of cargo, although some indication of cargo content may at times be inferred from the category of vessel type. The following is a partial summary of the listing of the types of vessels involved.

Type of vessels Vesse1

Freight Not known

Cargo

barge

Tankship Not Known

Tank

barge

$$
1,890
$$

Number of vessels involving Collisions while anchored, docking or undocking

59

66

17

3

36
Explosion and/or fire

27

To ferret out the uncoded reports for these incidents for the purpose of discovering if hazardous materials were partially or wholly the cargo and if building damage occurred and was significant would be impractical from the standpoint of time and expense.

The number of accidents in 1968 had increased 10.9 percent (annual growth rate of 2.7 percent) from 1964, while in the same period (see table 6) accidents in which hazardous materials were the cargo increased 117 percent (annual growth rate of 21.5 percent). It is expected that, by 1980 , marine 

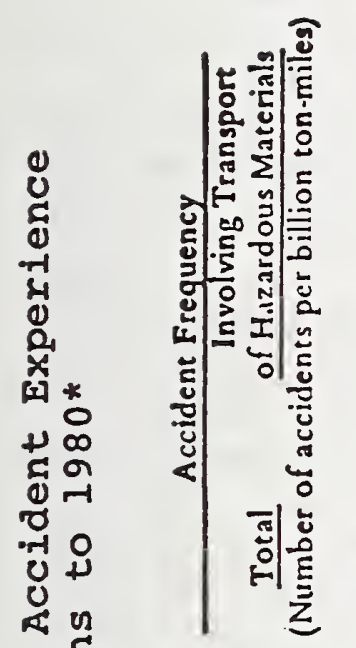

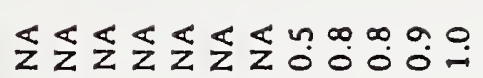
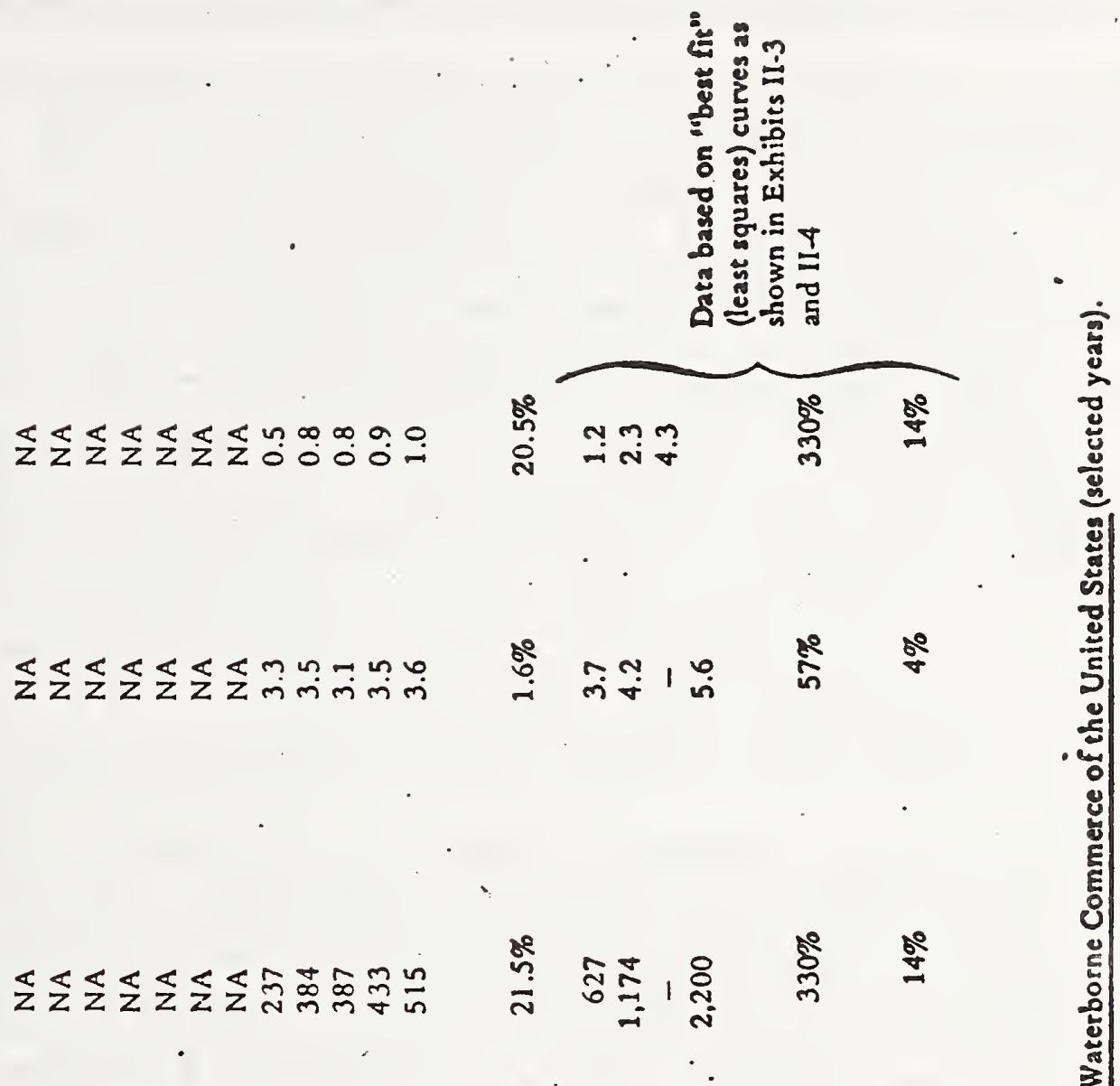

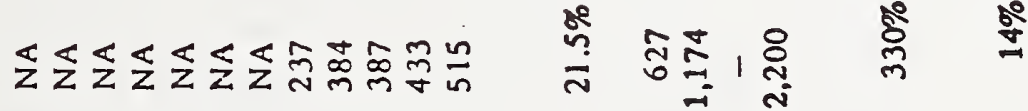

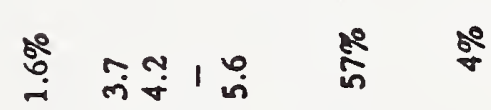

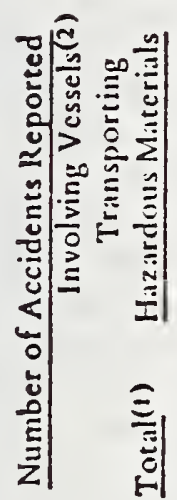

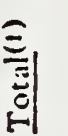

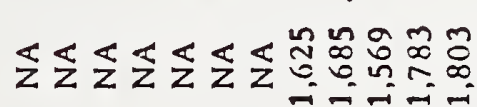

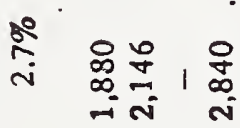

$\frac{\pi}{8} \quad \frac{4}{8}$

EN

ㅇํㅇำ

o.

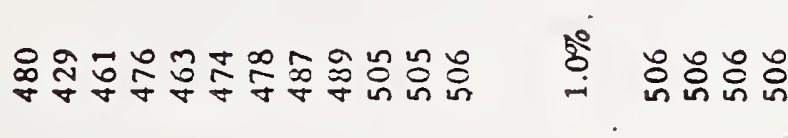
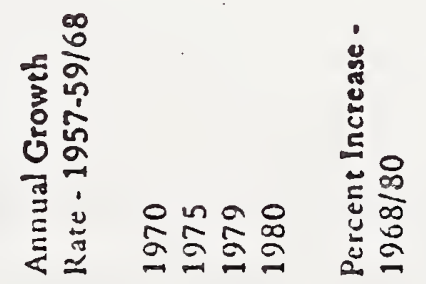
casualties will have increased 57 percent (at an annual growth rate of 4 percent); casualties involving hazardous materials are projected to increase 330 percent (an an annual growth rate of 14 percent [8]). It may well be assumed that the potential for building damage as a result of such an incident rate is also increasing, although not at the same rate.

The Texas City disaster of April 14, 1947 is the only documented instance of structural damage to buildings. However, no recent (within the last 25 years) instances of structural building damage were discovered in the course of this investigation, although the potential for such damage exists in a small number of cases. The increasing amount of water transportation of hazardous materials, particularly petroleum, and the increasing rate of casualties in which such materials are the cargo, will present a growing hazard in the future. Factors contributing to this risk include the location of fuel transfer terminals in densely populated areas, and the use of super-tankers with increased cargo capacities. With sufficient exposure, circumstances could arise such that a major catastrophe would result. 
5. MOTOR VEHICLE TRANSPORTATION OF HAZARDOUS MATERIALS

In 1969, the Factory Mutual Research Corporation performed an analysis of all freely available accident statistics concerning motor vehicles transporting hazardous materials [4]. Although some accident information was not available because it was not collected or not released, 3,887 accidents were adequately documented. The report indicates that these were probably representative of the total of 14,400 national hazardous material accidents which are believed to have occurred during the 30 month period between July 1966 and December 1968 .

The report [4] concluded that 69 percent of hazardous material accidents involved vehicles transporting petroleum products or other combustible or flammable liquids; 12 percent involved corrosive liquids; 10 percent involved explosives; and the remaining 9 percent involved miscellaneous poisons and radioactive materials. Of the petroleum product accidents (i.e., most of the 69 percent), 0.8 percent were believed to have led to explosions. No estimate was made of the explosions resulting from accidents involving the other commodities.

Using these tank truck figures, one can calculate the expected number of tank truck explosions per annum to be 32, that is 0.8 percent of 69 percent of 12/30ths of 14,400. A figure of 32 explosions is certainly not alarming when considering the portion of these accidents which are likely to be significant and which also take place in the built up areas. 
However, one must question both the applicability of a 19661968 average figure in the mid-1970's and also the possible number of explosions resulting from non-tank truck explosions. To estimate the change in tank truck accidents with time, the American Petroleum Institute figures on motor vehicle accidents in their indistry were consulted. Table 7 shows the change in accidents and accident rates over the ten year period 1961-1970. Although accident rates per mile driven have decreased significantly, the increase in total mileage has cancelled out the safety gain.

Tank truck accidents have increased at an annual rate of about 2.4 percent. Assuming that all of the additional accidents involved loaded trucks (which is very unlikely), then in the last four years there would be an increase from 32 (based on the 1966-1968 average) to about 37 explosions per year, still not a large number.

The explosions resulting from hazardous materials other than flammable liquids could not be easily analyzed. These commodities are flammable solids, explosives, oxidizing agents, acid anhydride, combustible compressed gasses, corrosive liquids, poison gas and radioactive materials. Since statistics are much less documented on these accidents, it was assumed that the probability of their unpublicized occurrence was negligible compared with tank truck accidents reported. Although the assumption is far from satisfactory, the paucity of data necessitates it. 


\section{TABLE 7}

Ten Years Comparison of Petroleum Industry

Tank Truck Accidents*

\begin{tabular}{lccccc} 
Year & $\begin{array}{c}\text { No. of } \\
\begin{array}{c}\text { Companies } \\
\text { Reporting }\end{array}\end{array}$ & $\begin{array}{c}\text { No. of } \\
\text { Trucks }\end{array}$ & $\begin{array}{c}\text { Nohicle Miles } \\
\text { Traveled } \\
\text { (Millions) }\end{array}$ & $\begin{array}{c}\text { No. } \\
\text { Accidents* }\end{array}$ & $\begin{array}{c}\text { Accidents/ } \\
\text { Milion } \\
\text { Miles }\end{array}$ \\
\hline 1961 & & 26,264 & 485 & 4,738 & 9.87 \\
1962 & 75 & 26,877 & 387 & 4,056 & 10.49 \\
1963 & 51 & 19,803 & 379 & 3,736 & 9.85 \\
1964 & 104 & 23,513 & 459 & 3,458 & 9.50 \\
1965 & 152 & 27,390 & 546 & 4,588 & 8.41 \\
1966 & 124 & 24,695 & 537 & 4,452 & 8.30 \\
1967 & 104 & 24,108 & 522 & 4.314 & 8.27 \\
1968 & 93 & 22,697 & 530 & 4,421 & 8.35 \\
1969 & 80 & 29,821 & 754 & 5,330 & 7.06 \\
1970 & 76 & 29,442 & 757 & 5,567 & 7.35
\end{tabular}

*Figures taken from [15].

**The total accicient figures in 66-68 disagree with the average figure of [5] because of aiternative definitions of accident. 
The National Transportation Safety Board (NTSB), has shown considerable concern over the fact that construction above and below expressways has shown a marked increase in recent years. In the report, A Study of Safety Considerations in the Utilization of Airspace Over and Under Federally Aided Highways [16], the NTSB has described a number of alarming examples where the airspace above expressways is used for the construction of large multi-story buildings. The increased danger in locating structures above, rather than alongside, roadways is difficult to assess whithout examining the dynamics of hypothetical explosions. However, the obvious increase in fire hazard should be kept in mind. The Board is awaiting actions from the Department of Transportation on recommendations made in the above-named report [16]. 


\section{RAILROAD TRANSPORTATION OF HAZARDOUS MATERIALS}

Over the six-year period, 1965-1970, 3,858 railroad tank cars were involved in 2,321 accidents in the United States and Canada (see reference [17]). Of these, 625 cars, lost lading due to mechanical damage. This represents approximately 3.9 mechanically damaged tank cars per thousand tank cars per year. (Average number of cars in service 19651970 was $164,730$.$) A large proportion of these were limited$ to minor leaks with partial lading loss as the only consequence.

Only 3 accidents involved explosions which caused structural damage to neighboring properties. These three (Dunreith, Indiana, January 1, 1968; Laurel, Mississippi, January 25, 1969; Crescent City, Illinois, June 21, 1970) contributed $\$ 10.6$ million damage, of which approximately $\$ 3.2$ million was due to the explosions, with the remainder attributed to fire damage before and after the explosions. This represents a tremendous part of the total estimated damage over the six years, which was $\$ 23.3$ million.

The presence of a study on railroad tank car safety (i.e., [18]), combined with others, demonstrates the Federal Railroad Administration's (FRA) determination to limit these incidents and their catastrophic damage. The effects of FRA pressure, however, will be difficult to assess if traffic levels of dangerous materials continue to increase. (In this regard, the Office of Hazardous Materials of the Department of Transportation is currently strengthening its effort 
to acquire more meaningful data on this general subject).

Assuming that the two phenomena have opposite and somewhat equal effects, damage can be expected to remain on the order of that of 1965-70. It has been suggested in a report by the Association of American Railroads [18] that this period is, in fact, not at all representative, with 1969 alone contributing over 5 times the average annual number of major ruptures. The six years of data imply:

1. An explosion of a ruptured tank car causes structural damage on an average of once every two years; and

2. An average damage of $\$ 3.5$ million from each of these explosions, where $\$ 1.05$ million is due to the explosion itself.

The accident statistics of 1971-72 confirm the first result, with exactly one explosion damaging residences in East St. Louis, Illinois. The extent of damage, however, was somewhat larger than the average figure of $\$ 3.5$ million.

An analysis has been made of costs and benefits derived from adding safety devices to existing tank cars in [17]. Design improvements considered were head shields, shell shields, bottom fitting shields, top fitting shields, coupler shields, and rocketing shields (rocketing is defined as the propulsion of large segments of tank cars caused by explosions). It is estimated that had rocketing shields been applied to all the cars of the types involved in previous explosions, a savings 
of over $\$ 400$ per car in rocketing costs alone would have been realized over the 30 year lifetime of the car. This is not necessarily the only alternative, for applying thermal shields to the same cars would eliminate rocketing caused by fire damage and additional non-rocketing damage caused by fire. It is estimated that a rocketing shield and a thermal sheel shield would yield a total savings of over $\$ 1,200$ per car. The best combination can not be determined, however, until/the engineering costs of installing the shields is estimated.

Tank car safety devices are only one aspect currently under investigation by the FRA. Additional studies have considered the advantages of limiting tank size and relocating tank cars in train make ups to name a few. One would hope that the Federal Railroad Safety Act of 1970 has had an effect on accident rates which has not yet been reflected in the data of $[17]$. 


\section{STORAGE OF HAZARDOUS MATERIALS}

Hazardous material storage facilities provide a somewhat different risk to their environment, since their location is fixed and generally well known. Railroad or motor transportation of hazardous materials is not as often considered a problem when selecting a location for construction. This might be the reason that fewer cases of destruction of buildings by explosions at storage facilities are recorded.

Storage facilities are known to exist at every petroleum refining plant, at distributing facilites where water carriers supply railroads or railroad carriers supply motor vehicle carriers, and where large-scale users deem it more economical. Storage tanks are now located in many densely populated areas including Providence, Boston, Philadelphia, and Staten Island [19]. The latter city was involved in an explosion in early 1972 killing several workmen who were cleaning the tank from inside.

Although little research has been uncovered on the likelihood of storage facility explosions, a novel approach to evaluating the risk of storing various quantities of material at various distances from residential areas has been made in reference [20], where Siccama has analyzed the hazard posed by the release of toxic gases into the storage facility's environment. Based on the probability of such an event (which can be reasonable estimated from past experience), the dispersion rate of the gases (which can be calculated as a function 
of weather conditions and other factors such as terrain contour, building configuration, etc.), the toxic effect of the gases, and the distance between the storage facility and the residential area, one can determine the maximum allowable storage quantity which will maintain a desired level of safety.

The analysis should be directly applicable to problems of explosions. One must, however, be able to calculate the analogous information required as input. The information relating distance to expected forces is not well known for most chemical explosions (as indicated in reference [3]), and the force required to do significant structural damage also needs to be estimated more accurately.

Siccama feels that this information can be obtained through close international cooperation. He also suggests that the technique could also be used for transportation analyses as well as for storage facilities. 


\section{SUMMARY}

The five preceding sections have examined five different handling procedures for hazardous materials. It has been emphasized throughout this report that the scarcity of data makes meaningful quantitative conclusions difficult. The following conclusions are considered to be justified by data, but not completely substantiated. They are presented for discussion purposes and consideration rather than firm decision-making.

Pipelines - There are basically two problems-natural gas pipelines and liquid pipelines. Natural gas accidents have been analyzed elsewhere [6]. There were 308 liquid pipeline accidents in 1971, down about 40 percert from 1968. The location of these pipelines in low density rural areas, combined with an increasing safety record, seems to indicate that this type of accident is not a serious risk at this time.

Water Carriers - In terms of past accidents, the risk to buildings seems to be negligible. The rapid increases in volumes handled and sizes of vessels could significantly alter the situation.

Motor Vehicles - On the average, 30-40 combustible liquid explosions can be expected per annum (rationwide). The number of these which might occasion significant damage to buildings cannot reasonably be estimated. Although accidents involving other dangerous commodities are documented, their 
frequency of occurrence in unknown. The increasing use of airspace over highways for buildings could increase the risk of this type of accident in the future.

Railroads - Some of the most serious accidents experienced to date have been associated with rail transport. In addition, railroad accidents, both actual and potential, have been subjected to the most extensive investigation. The knowledge required to improve the safety record seems to exist, along with a desire to use it. Without changes in procedures, we can probably expect serious accidents to continue at the rate of one every two years, with explosion damage to structures of about $\$ 1.05$ million per accident. Storage - This area has received relatively little emphasis in the past, likely due to a good safety record. Documented accidents seem to have been caused by failures in processing facilities which, for obvious reasons, are located on the same sites as storage facilities. This problem appears to be the most conducive for further analytical examination. 


\section{LIST OF REFERENCES}

1. Somes, N. F., "Abnormal Loading on Buildings and Progressive Collapse", NBSIR 73-221, National Bureau of Standards, Washington, D.C., 20234, May 1973.

2. Durand, J. D., Association of Oil Pipelines, Press Release, Washington, D.C., April 25, 1972.

3. Strehlow, R. A., "Unconfined Vapor Cloud Explosions - An Overview", Report AAE TR 72-1, UILU-ENG. 72 0501, Aeronautical and Astronautical Engineering Department, University of Illinois, Urbana, Illinois, February 1972.

4. Krasner, L. M. , Motor Vehicle Standards for Hazardous Material Transporation, prepared by Factory Mutual Research Corporation for DOT Contract \#FH-1l-6897, Report available from NBS Clearinghouse, Springfield, Va., Document \#PB192 167.

5. National Transportation Safety Board, Annual Report to the Congress of the United States - 1971, Available from U.S. Government Printing office, Washington, D.C., Stock \#5000-0053.

6. Burnett, E. F. P., Somes, N. F., and Leyendecker, E.V., "Residential Buildings and Gas-Related Explosions", NBSIR 73-208, National Bureau of Standards, Washington, D.C., 20234, June 1973.

7. Office of Pipeline Safety, Summary of Liquid Pipeline Accidents Reported on DOT Form 700-1, Annual Reports for years 1968-71.

8. "Analysis of the Safety of Transportation of Hazardous Materials on the Navigable Waters of the United States." Report Number: NTSB-MSS-72-2. National Transportation Safety Board. Washington, D.C., March 15, 1972.

9. Marine Casualty Report: Collision Involving sS African Star and $M / V$ Mid-West Cities and a two in Mississippi River on March 16, 1968." Department of Transportation, Washington, D.C., Nov. 10, 1970.

10. Marine Casualty Report: Collision Involving SS Union Faith and $M / V$ Warren $J$. Doucet and Tow in Mississippi River on April 6, 1969. Department of Transportation, Washington, D.C., Nov. 10, 1970. 
11. Waterborne Commerce of the United States: Calendar Year 1970. Part 5, Department of the Army, Corps of Engineers, Vicksburg, Mississippi. Also conversations with the following individuals and organizations:

12. Society of Navel Architects, New York, N.Y.

13. Proceedings of the Marine Safety Council, Vol. 28, No. 12 United States Coast Guard, Washington, D.C., Dec. 1971.

14. 1970 Inland Waterborne Commerce Statistics, American Waterways Operators, Inc., Washington, D.C., Nov. 1971.

15. Summary of Motor Vehicle Accidents in the Petroleum Industry for 1970, American Petroleum Institute, Division of Statistics and Economics, May 1971.

16. National Transportation Safety Board, A Study of Safety Considerations in the Utilization of Airspace Over and Under Federally Aided Highways, Report \#SB60-34, April 6,1969 .

17. Railroad Tank Car Safety Research and Test Project: Final Phase 2 Report on Accicent Review, Association of American Railroads, Report \#RA-02-2-18, Chicago, August 1972.

18. Railroad Tank Car Safety Research and Test Project: Summary of Ruptured Tank Cars Involved in Past Accidents, Association of American Railroads Report \#RA-01-2-7, Chicago, July 1971 .

19. Lt. Commander Danahy. Hazardous' Materials Division, U.S. Coast Guard, Washington, D.C.

20. Siccama, E. H., "The Environmental Risk Arising from the Bulk Storage of Dangerous Chemicals", from Proceedings Conference on Hazard Evaiuation and Risk Analysis, Houston, August 1971, Sponscired by National Academy of Sciences, Washington, D.C. 



\begin{tabular}{|c|c|c|}
\hline \begin{tabular}{c|c} 
U.S. DEPT. OF COMM. & I. PHIIIK ATION (OR RIPORT NO. \\
BIBLIOGRAPHIC DATA & IR $73-412$ \\
SHEET & IR
\end{tabular} & $\begin{array}{l}\text { 2. Gov't Accession } \\
\text { No. }\end{array}$ & 3. Recipicant's Accession No. \\
\hline \multirow{2}{*}{\multicolumn{2}{|c|}{$\begin{array}{l}\text { 4. TITLE ANI SUBTITI: } \\
\text { The Incidence of Hazardous Material Accidents } \\
\text { During Transportation ard Storage }\end{array}$}} & \multirow{2}{*}{ 5. Publication I)atc } \\
\hline & & \\
\hline \multicolumn{2}{|c|}{$\begin{array}{l}\text { 7. AUTHOR(S) } \\
\text { W. A. Steele, D. Bowser, and R. E. Chapman }\end{array}$} & 8. Performing Organ. Report No. \\
\hline \multirow{2}{*}{\multicolumn{2}{|c|}{$\begin{array}{l}\text { 9. PERFORMING ORGANIZATION NAME ANI ADDRESS } \\
\qquad \begin{array}{l}\text { NATIONAL BUREAU OF STANDARDS } \\
\text { DEPARTMENT OF COMMERCE } \\
\text { WASHINGTON, D.C. } 20234\end{array}\end{array}$}} & $\begin{array}{l}\text { 10. Project/Task/Work Unit No. } \\
4314426\end{array}$ \\
\hline & & 11. Contract/Grant No. \\
\hline \multirow{2}{*}{\multicolumn{2}{|c|}{$\begin{array}{l}\text { 12. Sponsoring Organization Name and Complete Address (Street, City, State, ZIP) } \\
\text { Center for Building Technology } \\
\text { National Bureau of Standards } \\
\text { Washington, D. C. } 20234\end{array}$}} & $\begin{array}{l}\text { 13. Type of Report \& Period } \\
\text { Covered } \\
\text { Final Report }\end{array}$ \\
\hline & & 14. Sponsoring Agency Code \\
\hline
\end{tabular}

15. SUPPLEMENTARY NOTES

16. ABSTRACT (A 200-word or less factual summary of most significant information. If document includes a significant bibliography or literature survey, mention it here.)

This report is one of a series describing background research concerning the incidence of abnormal loading. The report is organized in terms of modes of hazardous material transportation and storage. These modes - pipeline, water, motor vehicle, and railroad transportation systems - are addressed in four sections with storage systems discussed in a fifth. The sections depend on the amount of available data, rather than the risk involved in an accident. A summary of the results is presented in the last section. On the whole, there is little empirical evidence to substantiate a threat to buildings from hazardous materials transport. However, trends in volumes shipped in proximity to structures of interest raises the prospect of future incidents.

17. KEY WORDS (six to twelve entries; alphabetical order; capitalize only the first letter of the first key word unless a proper name; separated by semicolons)

Accidents; hazardous material; storage of hazardous material; transportation of hazardous material.

X Unlimited

For Official Distribution. Do Not Release to NTIS

Order From Sup. of Doc., U.S. Government Printing Office Washington, D.C. 20402, SD Cat. No.C13

Order From National Technical Information Service (NTIS) Springfield, Virginia 22151

\begin{tabular}{|l|c|}
\hline $\begin{array}{l}\text { 19. SECURITY CLASS } \\
\text { (THIS REPURT) }\end{array}$ & 21. NO. OF PAGES \\
UNCL ASSIFIED & 42 \\
\hline $\begin{array}{l}\text { 20. SECURITY CLASS } \\
\text { (THIS PAGE) } \\
\text { UNCLASSIFIED }\end{array}$ & 22. Price \\
\hline
\end{tabular}




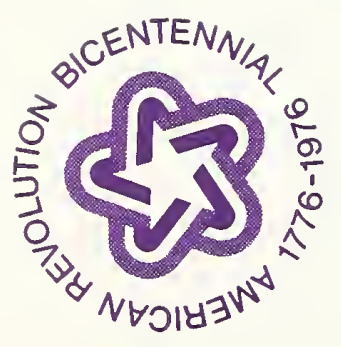

